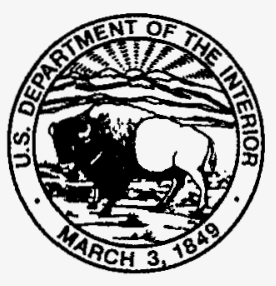

\title{
Thickness of Surficial Sediment at and near the Idaho National Engineering Laboratory, Idaho
}

U.S. Geological Survey

Open-File Report 96-330
- UEIVED

AUG 221996

OSTI

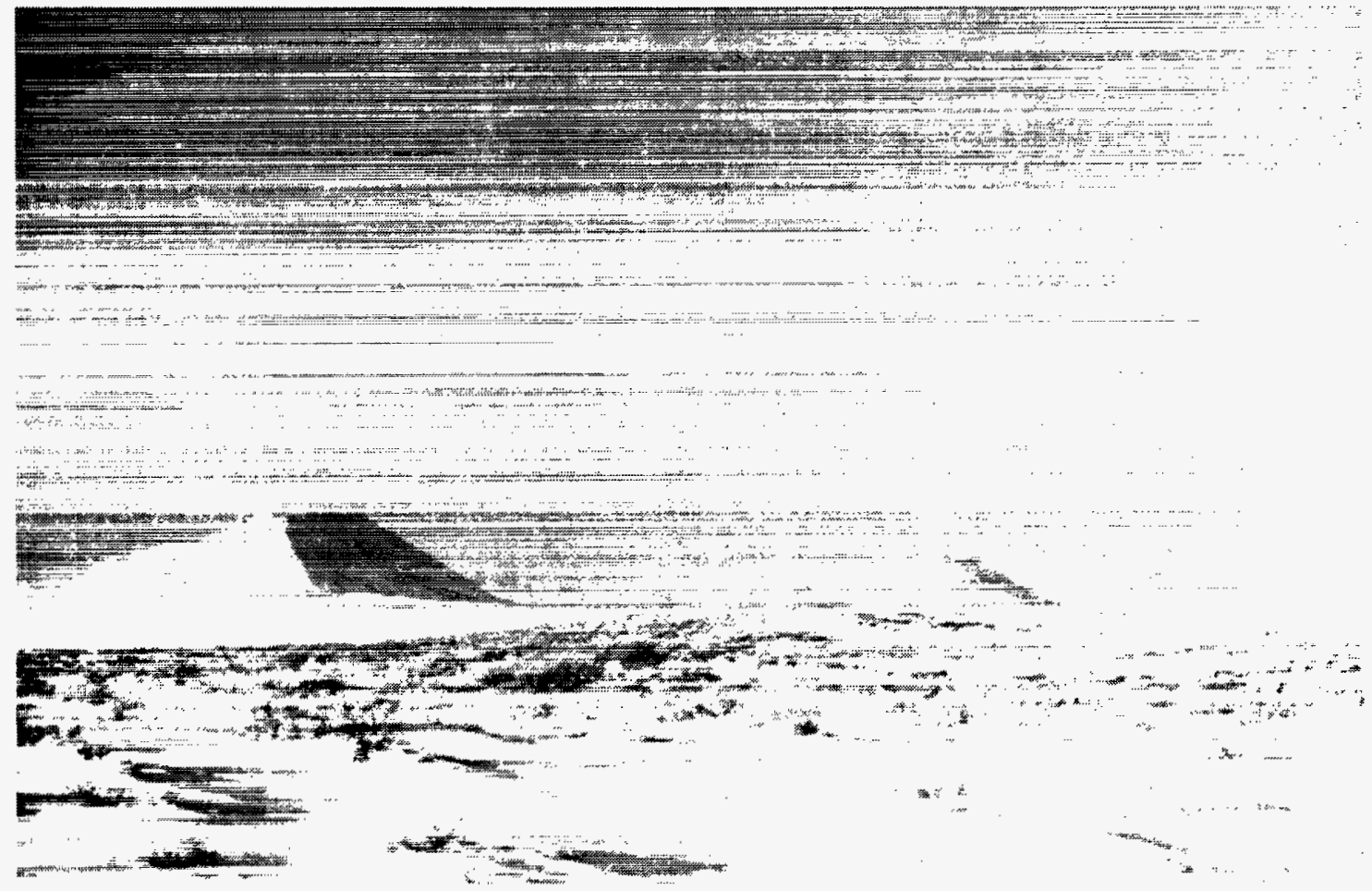

Prepared in cooperation with the

U.S. Department of Energy 
Cover: From left, East Butte, Middle Butte, and Big Southern Butte, Idaho National Engineering Laboratory

Photograph courtesy of T.D. Reynolds, formerly with U.S. Department of Energy, Environmental Sciences Branch 


\section{Thickness of Surficial Sediment at and near the Idaho National Engineering Laboratory, Idaho}

by S.R. Anderson, Michael J. Liszewski, and Daniel J. Ackerman

U.S. GEOLOGICAL SURVEY

Open-File Report 96-330

Prepared in cooperation with the U.S. DEPARTMENT OF ENERGY

Idaho Falls, Idaho June 1996 


\section{U.S. DEPARTMENT OF THE INTERIOR \\ BRUCE BABBITT, Secretary}

U.S. GEOLOGICAL SURVEY

GORDON P. EATON, Director

For additional information write to: Copies of this report can be purchased from:

U.S. Geological Survey

Earth Science Information Center

U.S. Geological Survey

INEL, MS 4148

Open-File Reports Section

Box 25286, MS 517

P.O. Box 2230

Idaho Falls, ID 83403

Denver Federal Center

Denver, CO 80225 


\section{DISCLAIMER}

Portions of this document may be illegible in electronic image products. Images are produced from the best available original document. 


\section{DISCLAIMER}

This report was prepared as an account of work sponsored by an agency of the United States Government. Neither the United States Government nor any agency thereof, nor any of their employees, makes any warranty, express or implied, or assumes any legal liability or responsibility for the accuracy, completeness, or usefulness of any information, apparatus, product, or process disclosed, or represents that its use would not infringe privately owned rights. Reference herein to any specific commercial product, process, or service by trade name, trademark, manufacturer, or otherwise does not necessarily constitute or imply its endorsement, recommendation, or favoring by the United States Government or any agency thereof. The views and opinions of authors expressed herein do not necessarily state or reflect those of the United States Government or any agency thereof. 


\section{CONTENTS}

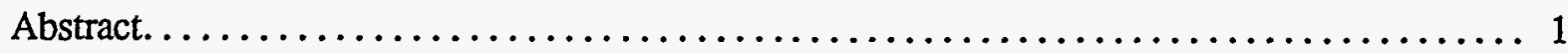

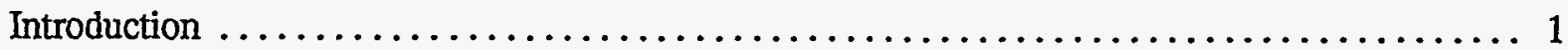

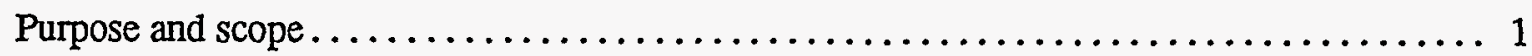

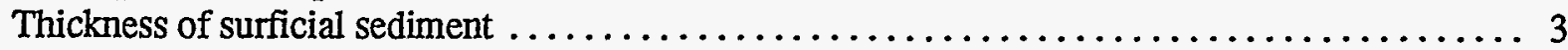

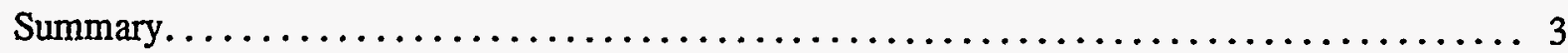

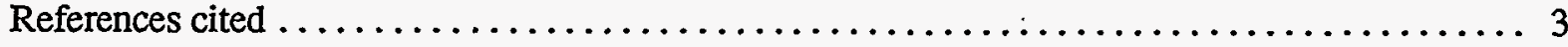

\section{FIGURES}

Figures 1-9. Maps showing:

1. Location of the Idaho National Engineering Laboratory and selected facilities. . . . . . . . . . . . . . . . . . . . . . . . . . . 2

2. Locations of wells used to determine thickness of surficial sediment at and near the Idaho National Engineering Laboratory $\ldots \ldots \ldots \ldots \ldots \ldots \ldots$

3. Locations of wells used to determine thickness of surficial sediment at and near the Idaho Chemical Processing Plant, Test Reactor Area, and Central Facilities Area. ...........................6 6

4. Locations of wells used to determine thickness of surficial sediment at and near the Radioactive Waste Management Complex ............... 7

5. Locations of wells used to determine thickness of surficial sediment at and near the Contained Test Facility and Test Area North . . . . . . . . . . . 8

6. Thickness of surficial sediment in wells at and near the Idaho National Engineering Laboratory............................... 13

7. Thickness of surficial sediment in wells at and near the Idaho Chemical Processing Plant, Test Reactor Area, and Central Facilities Area . . . . . . . . . 14

8. Thickness of surficial sediment in wells at and near the Radioactive Waste Management Complex ............................ 15

9. Thickness of surficial sediment in welis at and near the Contained Test Facility and Test Area North............................ 16

\section{TABLES}

Table 1. Thickness of surficial sediment in wells at and near the Idaho National

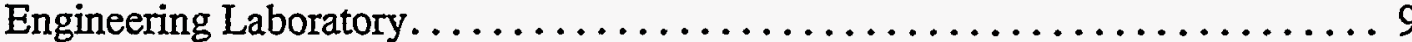

\section{CONVERSION FACTORS}

\begin{tabular}{rll}
\hline Multiply & By & To Obtain \\
\hline foot (ft) & 0.3048 & meter \\
square mile $\left(\mathrm{mi}^{2}\right)$ & 2.590 & square kilometer \\
\hline
\end{tabular}




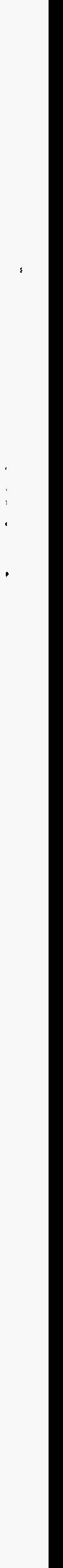




\title{
Thickness of Surficial Sediment at and near the Idaho National Engineering Laboratory, Idaho
}

\author{
by S.R. Anderson, Michael J. Liszewski, and Daniel J. Ackerman
}

\section{Abstract}

Thickness of surficial sediment was determined from natural-gamma logs in 333 wells at and near the Idaho National Engineering Laboratory in eastem Idaho to provide reconnaissance data for future site-characterization studies. Surficial sediment, which is defined as the unconsolidated clay, silt, sand, and gravel that overlie the uppermost basalt flow at each well, ranges in thickness from 0 feet in seven wells drilled through basalt outcrops east of the Idaho Chemical Processing Plant to 313 feet in well Site 14 southeast of the Big Lost River sinks. Surficial sediment includes alluvial, lacustrine, eolian, and colluvial deposits that generally accumulated during the past 200 thousand years. Additional thickness data, not included in this report, are available from numerous auger holes and foundation borings at and near most facilities.

\section{INTRODUCTION}

The Idaho National Engineering Laboratory (INEL) is operated by the U.S. Department of Energy (DOE) and covers about $890 \mathrm{mi}^{2}$ of the eastern Snake River Plain in eastern Idaho (fig. 1). Facilities at the INEL are used in the development of peacetime atomic-energy applications, nuclear safety research, defense programs, and advanced energy concepts. Liquid radionuclide and chemical wastes generated at these facilities have been discharged to onsite infiltration ponds and disposal wells since 1952. Liquid-waste disposal has resulted in detectable concentrations of several waste constituents in water in the Snake River Plain aquifer underlying the INEL (Orr and Cecil, 1991).

Concern about the potential for migration of radioactive and chemical wastes in the unsaturated zone and aquifer has resulted in numerous studies of the subsurface at the INEL. In 1988, the U.S. Geological Survey (USGS) in cooperation with the DOE, began a study of the stratigraphy of basalt and sediment underlying the INEL to determine stratigraphic relations that might affect the movement of wastes. Three earlier reports, Anderson and Lewis (1989), Anderson (1991), and Anderson and Bowers (1995), describe stratigraphic relations and their implications regarding the movement of wastes at the Radioactive Waste Management Complex (RWMC), the Idaho Chemical Processing Plant (ICPP), the Test Reactor Area (TRA), and Test Area North (TAN) (fig. 1). A fourth report, Anderson and others (1996), describes stratigraphic relations in 333 wells at and near the INEL and includes revised relations for the RWMC, ICPP, TRA, and TAN. Each of these reports describes the thickness of surficial sediment; data are contoured at the RWMC, ICPP, TRA, and TAN, and Anderson and others (1996) subdivide the sediment into stratigraphic units.

\section{Purpose and Scope}

This report describes the thickness of surficial sediment determined from natural-gamma logs in 333 wells at and near the INEL (figs. 2-5 and table 1 , located at back of this report). Surficial sediment, disregarding stratigraphic criteria, is defined as the unconsolidated clay, silt, sand, and gravel that overlie the uppermost basalt flow at each well. Surficial sediment includes alluvial, lacustrine, eolian, and colluvial deposits that generally accumulated during the last 200 thousand years.

This report was designed to provide reconnaissance data for future site-characterization studies, such as those that would be required for building sites, storage tanks, pipelines, landfills, and waste ponds. Additional thickness data, not included in 


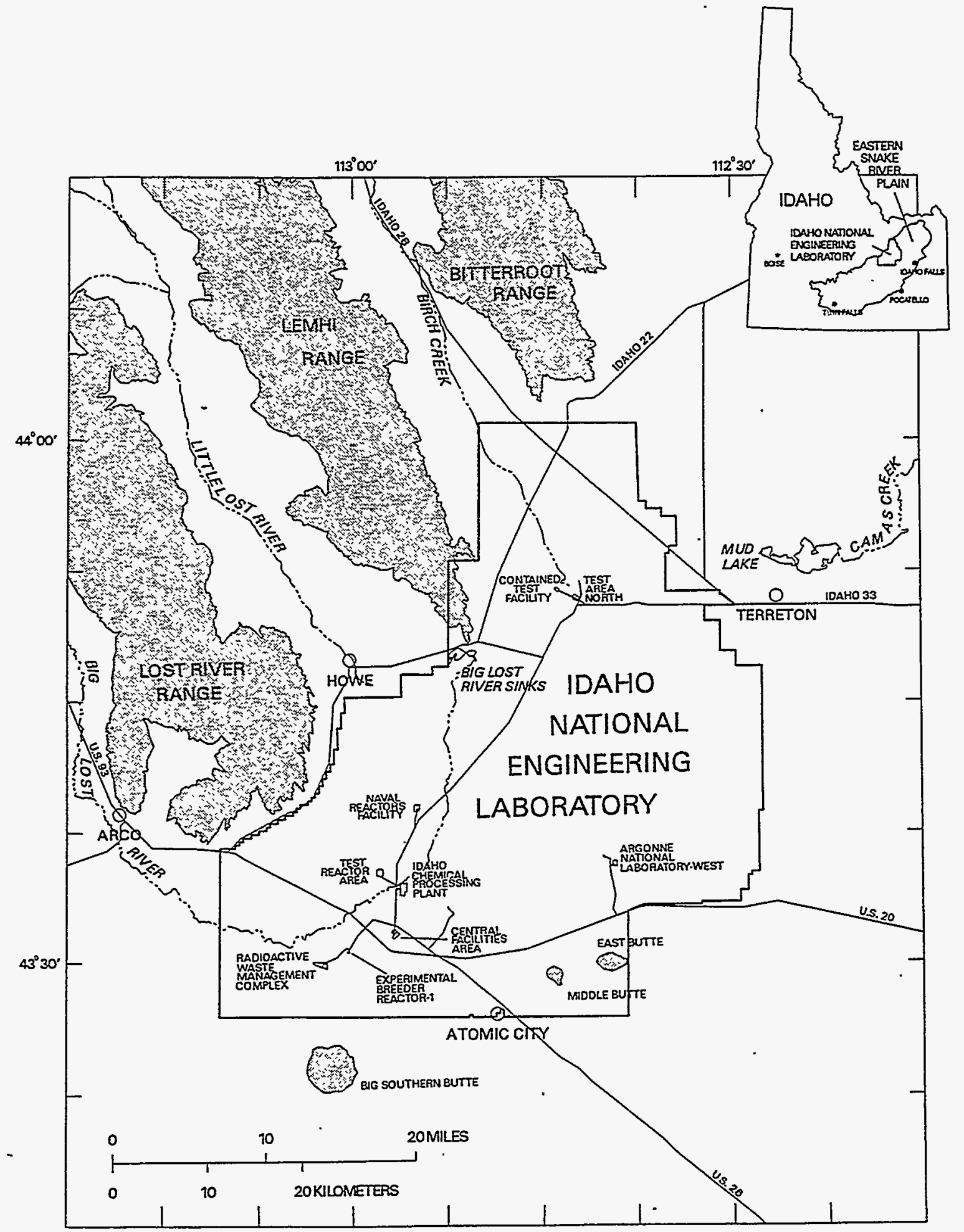

Figure 1. Location of the Idaho National Engineering Laboratory and selected facilities. 
this report, are available from numerous auger holes and foundation borings at and near most facilities. Distribution of surficial sediment is described by Kuntz and others (1994). Mineralogy and grain size of surficial sediment and selected sedimentary interbeds are described by Bartholomay and others (1989), Bartholomay (1990), and Reed and Bartholomay (1994).

\section{THICKNESS OF SURFICIAL SEDIMENT}

Surficial sediment covers much of the INEL and adjacent areas, but is thickest in a zone that extends northeastward from the Central Facilities Area (CFA) to Mud Lake (fig. 6, located at the back of this report) (Kuntz and others, 1994). Areas inside this zone are covered by alluvial, lacustrine, and eolian deposits derived from the Big Lost River, Little Lost River, Birch Creek, Camas Creek, Mud Lake, and ancient Lake Terreton. Areas outside of this zone are covered mainly by basalt and a veneer of wind-blown sediment and colluvium. Facilities inside the zone of thickest sediment accumulation include the CFA, ICPP, TRA, and TAN; the Contained Test Facility (CTF) and Naval Reactors Facility (NRF) also lie within this zone (fig. 1). Facilities that overlie shallow basalt include the RWMC, the Experimental Breeder Reactor-1 (EBR-1), and Argonne National Laboratory-West (ANL-W).

Thickness of surficial sediment ranges from 0 feet in wells NPR Test, NPR WO-2, PBF \#2, PBF(CW), PBF(WW), Sdd-1, and Sdd-2 that were drilled through basalt outcrops east of the ICPP to $313 \mathrm{ft}$ in well Site 14, southeast of the Big Lost River sinks (fig. 1; and figs. 6-9 and table 1 , located at the back of this report). Thickness of sediment in wells ranges from about 10 to $30 \mathrm{ft}$ at the CFA and NRF, about 20 to $60 \mathrm{ft}$ at the CTF and TAN, and about 20 to $70 \mathrm{ft}$ at the ICPP and TRA. Facilities where sediment thickness is least include the RWMC, EBR-1, and ANL-W; thickness of sediment in wells ranges from about 5 to $20 \mathrm{ft}$ at the RWMC and EBR-1 and is less than $10 \mathrm{ft}$ at ANL-W. Areas of thickest sediment accumulation occur near and southeast of the Big Lost River sinks and near Terreton, southwest of Mud Lake; thickness of sediment ranges from 177 to $313 \mathrm{ft}$ in wells DH1B, DH2A,
$\mathrm{DH} 3$, and Site 14 and from 68 to $132 \mathrm{ft}$ in wells USGS 27, Ashcraft, Bamey North, Barney South, Callaway, and Cope. Most surficial sediment at and near the INEL accumulated during the last 200 thousand years, although deposits are younger than about 100 thousand years in the northem part of the RWMC and are about 470 thousand years old in the area of thickest accumulation near and southeast of the Big Lost River sinks (Anderson and others, 1996).

\section{SUMMARY}

Thickness of surficial sediment was determined from natural-gamma logs in 333 wells at and near the INEL to provide reconnaissance data for future site-characterization studies. Thickness of surficial sediment ranges from 0 feet in seven wells drilled through basalt outcrops east of the ICPP to $313 \mathrm{ft}$ in well Site 14, southeast of the Big Lost River sinks. In general, sediment thickness in wells ranges from about 5 to $20 \mathrm{ft}$ at the RWMC and EBR-1, about 10 to $30 \mathrm{ft}$ at the CFA and NRF, about 20 to $60 \mathrm{ft}$ at the CTF and TAN, and about 20 to $70 \mathrm{ft}$ at the ICPP and TRA; sediment thickness is less than $10 \mathrm{ft}$ at ANL-W. Sediment thickness ranges from 177 to $313 \mathrm{ft}$ in four wells near and southeast of the Big Lost River sinks and from 68 to $132 \mathrm{ft}$ in six wells southwest of Mud Lake near Terreton. Most surficial sediment was deposited during the last 200 thousand years, although sediment is younger than about 100 thousand years in the northem part of the RWMC and as old as about 470 thousand years in the area of thickest.accumulation. Additional thickness data, not included in this report, are available from numerous auger holes and foundation borings at and near most facilities.

\section{REFERENCES CITED}

Anderson, S.R., 1991, Stratigraphy of the unsaturated zone and uppermost part of the Snake River Plain aquifer at the Idaho Chemical Processing Plant and Test Reactors Area, Idaho National Engineering Laboratory, Idaho: U.S. Geological Survey WaterResources Investigations Report 91-4010 (DOE/ID-22095), $71 \mathrm{p}$. 
Anderson, S.R., Ackerman, D.J., Liszewski, M.J., and Freiburger, R.M., 1996, Stratigraphic data for wells at and near the Idaho National Engineering Laboratory, Idaho: U.S. Geological Survey Open-File Report 96-248, (DOE/ID22127) 27 p., 1 diskette.

Anderson, S.R., and Bowers, B., 1995, Stratigraphy of the unsaturated zone and uppermost part of the Snake River Plain aquifer at Test Area North, Idaho National Engineering Laboratory, Idaho: U.S. Geological Survey Water-Resources Investigations Report 954130, (DOE/ID-22122) $47 \mathrm{p}$.

Anderson, S.R. and Lewis, B.D., 1989, Stratigraphy of the unsaturated zone at the Radioactive Waste Management Complex, Idaho National Engineering Laboratory, Idaho: U.S. Geological Survey Water-Resources Investigations Report 89-4065 (DOE/LD-22080), $54 \mathrm{p}$.

Bartholomay, R.C., 1990, Mineralogical correlation of surficial sediment from area drainages with selected sedimentary interbeds at the Idaho National Engineering Laboratory, Idaho: U.S. Geological Survey WaterResources Investigations Report 90-4147 (DOE/ID-22092), 18 p.

Bartholomay, R.C., Knobel, L.L., and Davis, L.C., 1989, Mineralogy and grain size of surficial sediment from the Big Lost River drainage and vicinity, with chemical and physical characteristics of geologic materials from selected sites at the Idaho National Engineering Laboratory, Idaho: U.S. Geological Survey OpenFile Report 89-384 (DOE/ID-22081), 74 p.

Kuntz, M.A., Skipp, Betty, Lanphere, M.A., Scott, W.E., Pierce, K.L., Dalrymple, G.B., Champion, D.E., Embree, G.F., Page, W.R., Morgan, L.A., Smith, R.P., Hackett, W.R., and Rodgers, D.W., 1994, Geologic map of the Idaho National Engineering Laboratory and adjoining areas, eastem Idaho: U.S. Geological Survey Miscellaneous Investigations Map I-2330, scale 1:100,000.
Orr, B.R., and Cecil, L.D., 1991, Hydrologic conditions and distribution of selected chemical constituents in water, Snake River Plain aquifer, Idaho National Engineering Laboratory, Idaho, 1986 to 1988: U.S. Geological Survey Water-Resources Investigations Report 91-4047 (DOE/ID-22096), 56 p.

Reed, Michael F., and Bartholomay, R.C., 1994, Mineralogy of selected sedimentary interbeds at or near the Idaho National Engineering Laboratory, Idaho: U.S. Geological Survey Open-File Report 94-374 (DOE/ID-22116), $19 \mathrm{p}$. 


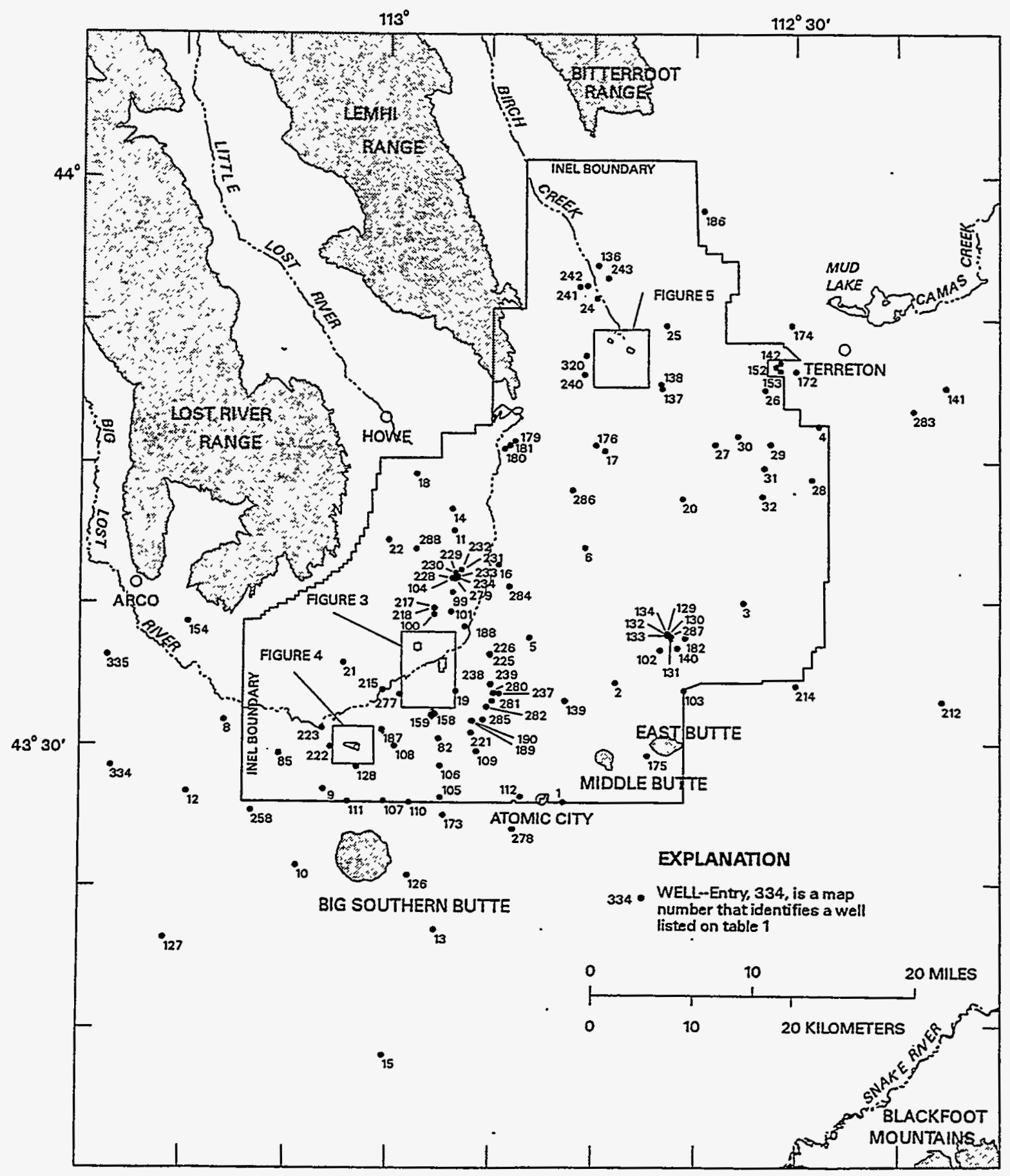

Figure 2. Locations of wells used to determine thickness of surficial sediment at and near the Idaho National Engineering Laboratory. 


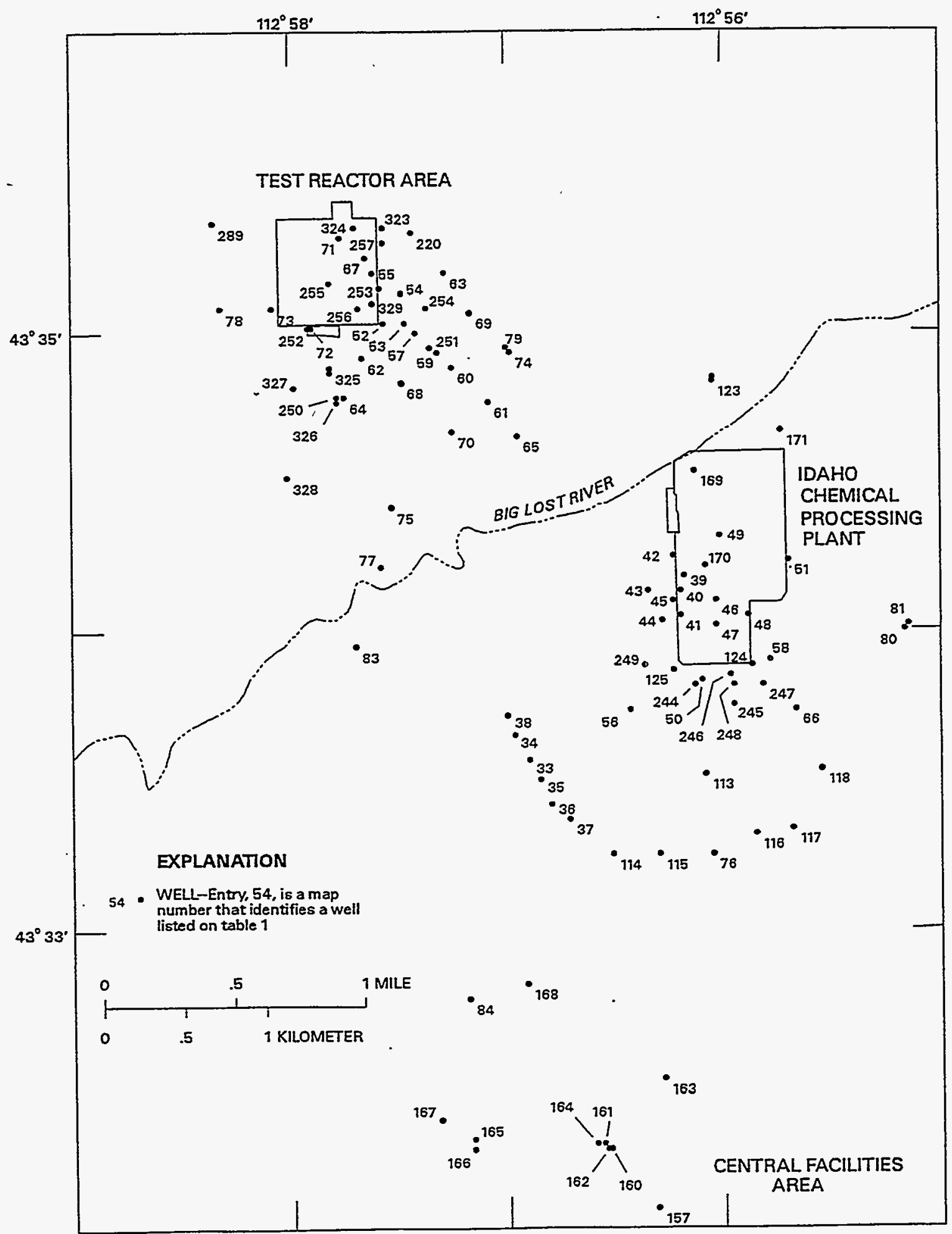

Figure 3. Locations of wells used to determine thickness of surficial sediment at and near the Idaho Chemical Processing Plant, Test Reactor Area, and Central Facilities Area (area keyed to figure 2). 


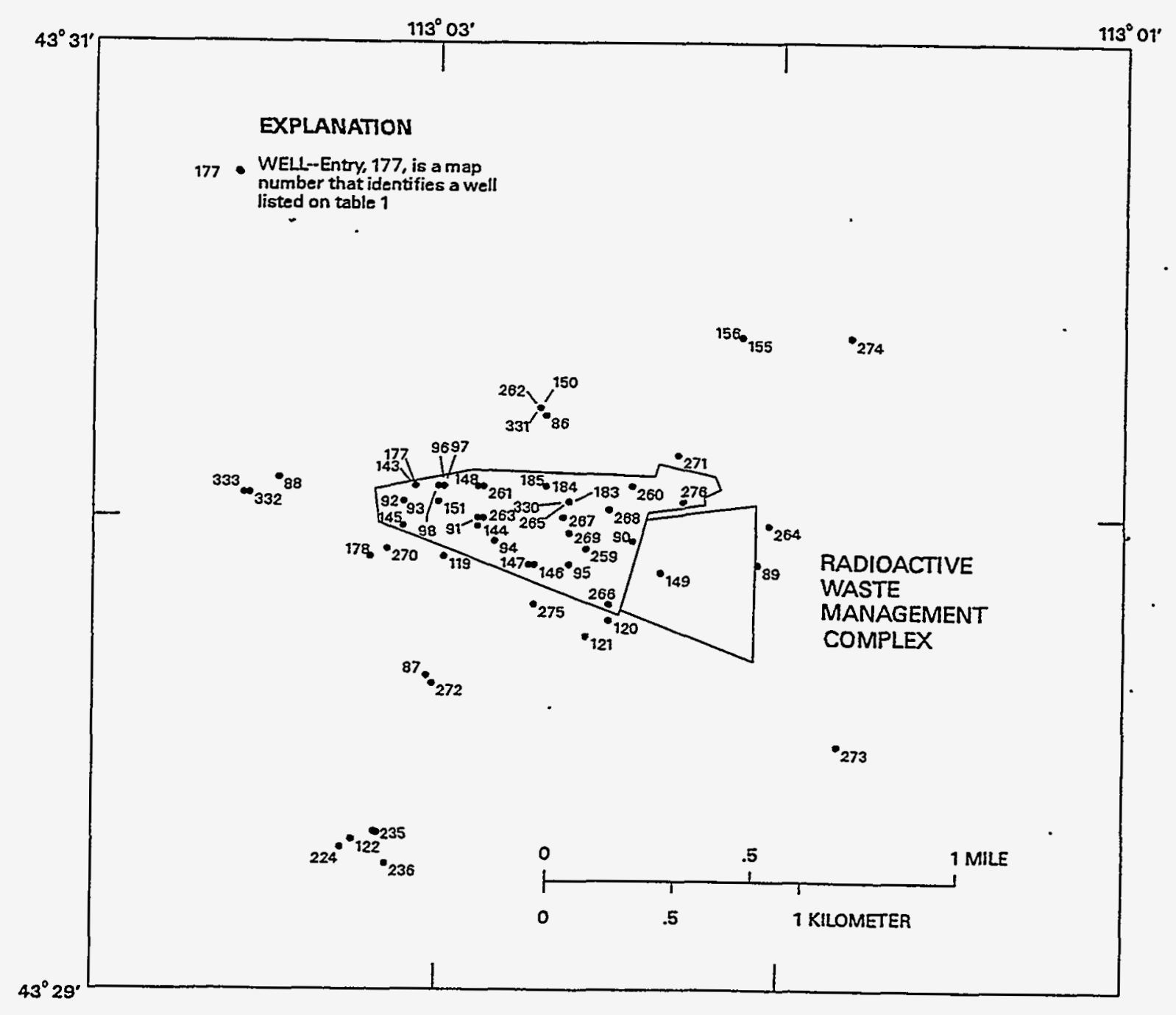

Figure 4. Locations of wells used to determine thickness of surficial sediment at and near the Radioactive Waste Management Complex (area keyed to figure 2). 


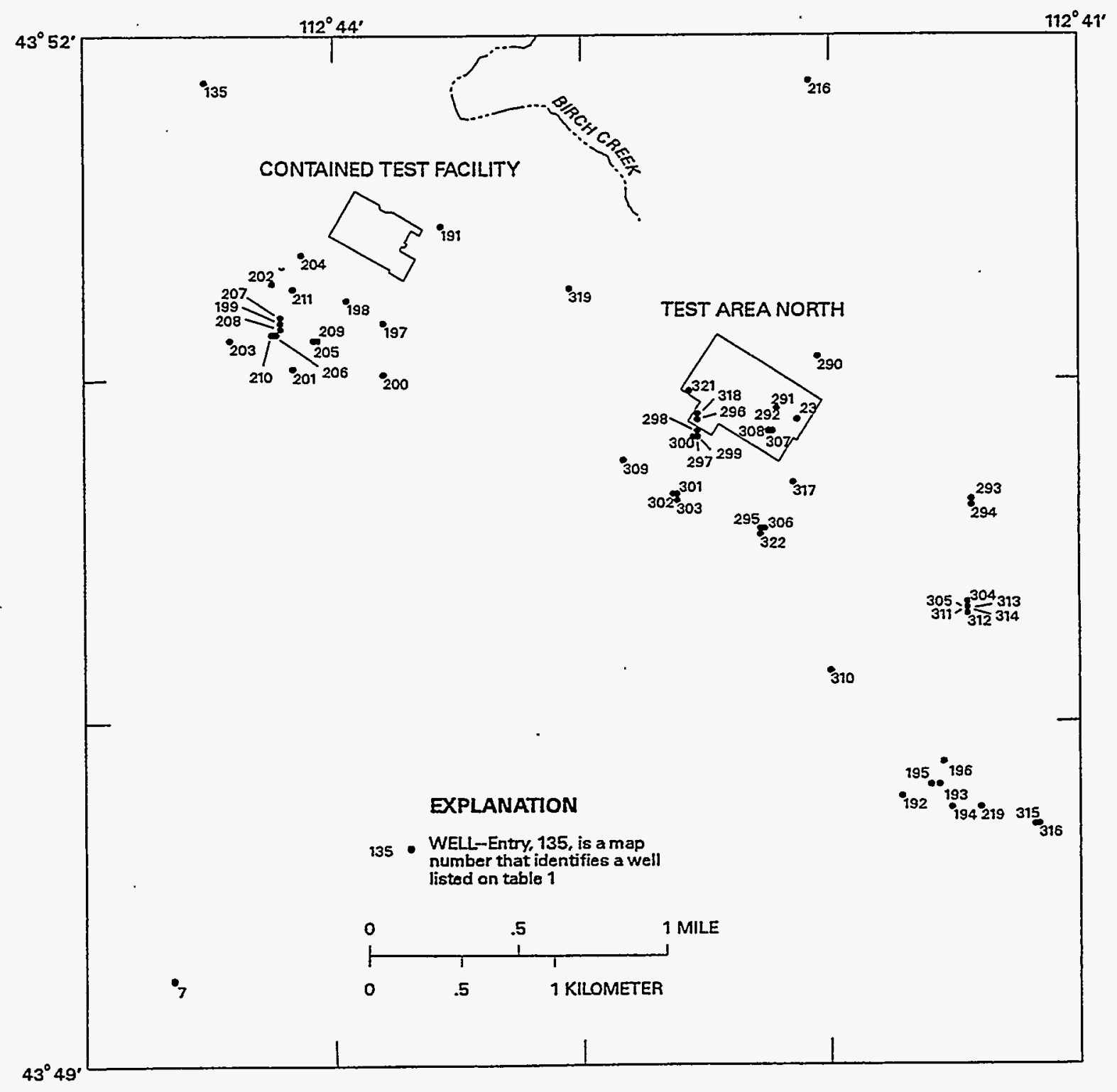

Figure 5. Locations of wells used to determine thickness of surficial sediment at and near the Contained Test Facility and Test Area North (area keyed to figure 2). 
Table 1. Thickness of surficial sediment in wells at and near the Idaho National Engineering Laboratory

IMap number: Entries, 1 through 335, identify the locations of wells on maps; numbers in parentheses, 2, 3, 4, and 5, correspond to figure numbers of maps. Thickness: Entries, 0 through 313, indicate the thickness of surficial sediment, in feet; numbers in parentheses indicate that data are posted on figures 6, 7, 8, or 9. Map numbers from Anderson and others (1996); map numbers 213 and 227 not used]

\begin{tabular}{|c|c|c|c|c|c|}
\hline Well identifier & $\begin{array}{c}\text { Map number } \\
\text { (Figure } \\
\text { number) } \\
\end{array}$ & $\begin{array}{c}\text { Thickness } \\
\text { (Figure } \\
\text { number) }\end{array}$ & Well identifier & $\begin{array}{l}\text { Map number } \\
\text { (Figure } \\
\text { number) }\end{array}$ & $\begin{array}{c}\text { Thickness } \\
\text { (Figure } \\
\text { number) }\end{array}$ \\
\hline USGS 1 & $1(2)$ & $6(6)$ & USGS 44 & $43(3)$ & $35(7)$ \\
\hline USGS 2 & $2(2)$ & $6(6)$ & USGS 45 & $44(3)$ & $53(7)$ \\
\hline USGS 3A & $3(2)$ & $13(6)$ & USGS 46 & $45(3)$ & $41(7)$ \\
\hline USGS 4 & $4(2)$ & $22(6)$ & USGS 47 & $46(3)$ & $40(7)$ \\
\hline USGS 5 & $5(2)$ & $7(6)$ & USGS 48 & $47(3)$ & $32(7)$ \\
\hline USGS 6 & $6(2)$ & $8(6)$ & USGS 49 & $48(3)$ & $27(7)$ \\
\hline USGS 7 & $7(5)$ & $123(9)$ & USGS 50 & $49(3)$ & $46(7)$ \\
\hline USGS 8 & $8(2)$ & $6(6)$ & USGS 51 & $50(3)$ & $31(7)$ \\
\hline USGS 9 & $9(2)$ & $9(6)$ & USGS 52 & $51(3)$ & $43(7)$ \\
\hline USGS 11 & $10(2)$ & $3(6)$ & USGS 53 & $52(3)$ & $45(7)$ \\
\hline USGS 12 & $11(2)$ & $49(6)$ & USGS 54 & $53(3)$ & $60(7)$ \\
\hline USGS 13 & $12(2)$ & $13(6)$ & USGS 55 & $54(3)$ & $42(7)$ \\
\hline USGS 14 & $13(2)$ & $7(6)$ & USGS 56 & $55(3)$ & $55(7)$ \\
\hline USGS 15 & $14(2)$ & $41(6)$ & USGS 57 & $56(3)$ & $49(7)$ \\
\hline USGS 16 & $15(2)$ & $0(6)$ & USGS 58 & $57(3)$ & $46(7)$ \\
\hline USGS 17 & $16(2)$ & $18(6)$ & USGS 59 & $58(3)$ & $22(7)$ \\
\hline USGS 18 & $17(2)$ & $6(6)$ & USGS 60 & $59(3)$ & $50(7)$ \\
\hline USGS 19 & $18(2)$ & $8(6)$ & USGS 61 & $60(3)$ & $60(7)$ \\
\hline USGS 20 & $19(2)$ & $21(6)$ & USGS 62 & $61(3)$ & $53(7)$ \\
\hline USGS 21 & $20(2)$ & $7(6)$ & USGS 63 & $62(3)$ & $56(7)$ \\
\hline USGS 22 & $21(2)$ & $10(6)$ & USGS 64 & $63(3)$ & $42(7)$ \\
\hline USGS 23 & $22(2)$ & $5(6)$ & USGS 65 & $64(3)$ & $51(7)$ \\
\hline USGS 24 & $23(5)$ & $57(9)$ & USGS 66 & $65(3)$ & $49(7)$ \\
\hline USGS 25 & $24(2)$ & $35(6)$ & USGS 67 & $66(3)$ & $23(7)$ \\
\hline USGS 26 & $25(2)$ & $24(6)$ & USGS 68 & $67(3)$ & $45(7)$ \\
\hline USGS 27 & $26(2)$ & $132(6)$ & USGS 69 & $68(3)$ & $50(7)$ \\
\hline USGS 28 & $27(2)$ & $8(6)$ & USGS 70 & $69(3)$ & $44(7)$ \\
\hline USGS 29 & $28(2)$ & $8(6)$ & USGS 71 & $70(3)$ & $55(7)$ \\
\hline USGS 30A & $29(2)$ & $15(6)$ & USGS 72 & $71(3)$ & $36(7)$ \\
\hline USGS 31 & $30(2)$ & $18(6)$ & USGS 73 & $72(3)$ & $56(7)$ \\
\hline USGS 32 & $31(2)$ & $17(6)$ & USGS 74 & $73(3)$ & $32(7)$ \\
\hline USGS 33 & $32(2)$ & $11(6)$ & USGS 75 & $74(3)$ & $43(7)$ \\
\hline USGS 34 & $33(3)$ & $32(7)$ & USGS 76 & $75(3)$ & $73(7)$ \\
\hline USGS 35 & $34(3)$ & $33(7)$ & USGS 77 & $76(3)$ & $13(7)$ \\
\hline USGS 36 & $35(3)$ & $30(7)$ & USGS 78 & 77 (3) & $67(7)$ \\
\hline USGS 37 & $36(3)$ & $37(7)$ & USGS 79 & $78(3)$ & $14(7)$ \\
\hline USGS 38 & $37(3)$ & $22(7)$ & USGS 80 & $79(3)$ & $41(7)$ \\
\hline USGS 39 & $38(3)$ & $33(7)$ & USGS 81 & $80(3)$ & $2(7)$ \\
\hline USGS 40 & $39(3)$ & $55(7)$ & USGS 82 & $81(3)$ & $3(7)$ \\
\hline USGS 41 & $40(3)$ & $44(7)$ & USGS 83 & $82(2)$ & $10(6)$ \\
\hline USGS 42 & $41(3)$ & $32(7)$ & USGS 84 & $83(3)$ & $58(7)$ \\
\hline USGS 43 & $42(3)$ & $52(7)$ & USGS 85 & $84(3)$ & $26(7)$ \\
\hline
\end{tabular}


Table 1. Thickness of surficial sediment in wells at and near the Idaho National Engineering Laboratory-Continued

\begin{tabular}{|c|c|c|c|c|c|}
\hline Well identifier & $\begin{array}{l}\text { Map number } \\
\text { (Figure } \\
\text { number) }\end{array}$ & $\begin{array}{l}\text { Thickness } \\
\text { (Figure } \\
\text { number) }\end{array}$ & Well identifier & $\begin{array}{c}\text { Map number } \\
\text { (Figure } \\
\text { number) }\end{array}$ & $\begin{array}{c}\text { Thickness } \\
\text { (Figure } \\
\text { number) }\end{array}$ \\
\hline USGS 86 & $85(2)$ & $34(6)$ & ANL-IWP-M2 & $130(2)$ & $9(6)$ \\
\hline USGS 87 & $86(4)$ & $3(8)$ & ANL-IWP-M3 & $131(2)$ & $7(6)$ \\
\hline USGS 88 & $87(4)$ & $5(8)$ & ANL-IWP-M4 & $132(2)$ & $5(6)$ \\
\hline USGS 89 & $88(4)$ & $10(8)$ & ANL-IWP-M5 & $133(2)$ & $8(6)$ \\
\hline USGS 90 & $89(4)$ & $5(8)$ & ANL-IWP-M6 & $134(2)$ & $5(6)$ \\
\hline USGS 91 & $90(4)$ & $9(8)$ & ANP \#6 & $135(5)$ & $35(9)$ \\
\hline USGS 92 & $91(4)$ & $19(8)$ & ANP \#7 & $136(2)$ & $4(6)$ \\
\hline USGS 93 & $92(4)$ & $13(8)$ & ANP \#9 & $137(2)$ & $76(6)$ \\
\hline USGS 93A & $93(4)$ & $11(8)$ & ANP \#10 & $138(2)$ & $61(6)$ \\
\hline USGS 94 & $94(4)$ & $12(8)$ & AREA II & $139(2)$ & $6(6)$ \\
\hline USGS 95 & $95(4)$ & $23(8)$ & Arbor Test 1 & $140(2)$ & $2(6)$ \\
\hline USGS 96 & $96(4)$ & $13(8)$ & R. Archer & $141(2)$ & $6(6)$ \\
\hline USGS 96A & $97(4)$ & $13(8)$ & Ashcraft & $142(2)$ & $110(6)$ \\
\hline USGS 96B & $98(4)$ & $14(8)$ & BG-76-1 & $143(4)$ & $7(8)$ \\
\hline USGS 97 & $99(2)$ & $38(6)$ & BG-76-2 & $144(4)$ & $12(8)$ \\
\hline USGS 98 & $100(2)$ & $6(6)$ & BG-76-3 & $145(4)$ & $18(8)$ \\
\hline USGS 99 & $101(2)$ & $32(6)$ & BG-76-4 & $146(4)$ & $7(8)$ \\
\hline USGS 100 & $102(2)$ & $4(6)$ & BG-76-4A & $147(4)$ & $2(8)$ \\
\hline USGS 101 & $103(2)$ & $3(6)$ & BG-76-5 & $148(4)$ & $11(8)$ \\
\hline USGS 102 & $104(2)$ & $19(6)$ & BG-76-6 & $149(4)$ & $4(8)$ \\
\hline USGS 103 & $105(2)$ & $22(6)$ & BG-77-1 & $150(4)$ & $4(8)$ \\
\hline USGS 104 & $106(2)$ & $3(6)$ & BG-77-2 & $151(4)$ & $18(8)$ \\
\hline USGS 105 & $107(2)$ & $15(6)$ & Barney North & $152(2)$ & $88(6)$ \\
\hline USGS 106 & $108(2)$ & $3(6)$ & Barney South & $153(2)$ & $74(6)$ \\
\hline USGS 107 & $109(2)$ & $10(6)$ & Butte City \#2 & $154(2)$ & $86(6)$ \\
\hline USGS 108 & $110(2)$ & $7(6)$ & $\mathrm{C}-1$ & $155(4)$ & $2(8)$ \\
\hline USGS 109 & $111(2)$ & $1(6)$ & C-1A & $156(4)$ & $4(8)$ \\
\hline USGS 110 & $112(2)$ & $2(6)$ & CFA 1 & $157(3)$ & $26(7)$ \\
\hline USGS 111 & $113(3)$ & $8(7)$ & CFA 2 & $158(2)$ & $10(6)$ \\
\hline USGS 112 & $114(3)$ & $24(7)$ & $\mathrm{CFA} 4$ & $159(2)$ & $7(6)$ \\
\hline USGS 113 & $115(3)$ & $20(7)$ & CFA LF 2-8 & $160(3)$ & $26(7)$ \\
\hline USGS 114 & $116(3)$ & $16(7)$ & CFA LF 2-9 & $161(3)$ & $27(7)$ \\
\hline USGS 115 & $117(3)$ & $20(7)$ & CFA LF 2-10 & $162(3)$ & $26(7)$ \\
\hline USGS 116 & $118(3)$ & $24(7)$ & CFA LF 2-11 & $163(3)$ & $25(7)$ \\
\hline USGS 117 & $119(4)$ & $14(8)$ & CFA LF 2-12 & $164(3)$ & $22(7)$ \\
\hline USGS 118 & $120(4)$ & $14(8)$ & CFA LF 3-8 & $165(3)$ & $13(7)$ \\
\hline USGS 119 & $121(4)$ & $3(8)$ & CFA LF 3-9 & $166(3)$ & $8(7)$ \\
\hline USGS 120 & $122(4)$ & $12(8)$ & CFA LF 3-10 & $167(3)$ & $26(7)$ \\
\hline USGS 121 & $123(3)$ & $29(7)$ & CFA LF 3-11 & $168(3)$ & $16(7)$ \\
\hline USGS 122 & $124(3)$ & $24(7)$ & CPP 2 & $169(3)$ & $35(7)$ \\
\hline USGS 123 & $125(3)$ & $31(7)$ & CPP Disp. & $170(3)$ & $47(7)$ \\
\hline USGS 124 & $126(2)$ & $4(6)$ & CPP 4 & $171(3)$ & $34(7)$ \\
\hline $1-27-14$ & $127(2)$ & $5(6)$ & Callaway & $172(2)$ & $68(6)$ \\
\hline A11A31 & $128(2)$ & $3(6)$ & Cerro Grande & $173(2)$ & $3(6)$ \\
\hline ANL-IWP-M1 & $129(2)$ & $8(6)$ & Cope & $174(2)$ & $100(6)$ \\
\hline
\end{tabular}


Table 1. Thickness of surficial sediment in wells at and near the Idaho National Engineering Laboratory-Continued

\begin{tabular}{|c|c|c|c|c|c|}
\hline Well identifier & $\begin{array}{l}\text { Map number } \\
\text { (Figure } \\
\text { number) }\end{array}$ & $\begin{array}{l}\text { Thickness } \\
\text { (Figure } \\
\text { number) }\end{array}$ & Well identifier & $\begin{array}{c}\text { Map number } \\
\text { (Figure } \\
\text { number) }\end{array}$ & $\begin{array}{l}\text { Thickness } \\
\text { (Figure } \\
\text { number) }\end{array}$ \\
\hline Corehole 1 & $175(2)$ & $8(6)$ & Main Gate Well & $221(2)$ & $11(6)$ \\
\hline Corehole 2A & $176(2)$ & $4(6)$ & NA 89-1 & $222(2)$ & $2(6)$ \\
\hline D-10 & $177(4)$ & $9(8)$ & NA 89-2 & $223(2)$ & $12(6)$ \\
\hline D-15 & $178(4)$ & $2(8)$ & NA 89-3 & $224(4)$ & $1(8)$ \\
\hline DH1B & $179(2)$ & $210(6)$ & NPR Test & $225(2)$ & $0(6)$ \\
\hline $\mathrm{DH} 2 \mathrm{~A}$ & $180(2)$ & $177(6)$ & NPR WO-2 & $226(2)$ & $0(6)$ \\
\hline DH3 & $181(2)$ & $>203(6)$ & NRF \#4 & $228(2)$ & $33(6)$ \\
\hline DH-50 & $182(2)$ & $6(6)$ & NRF \#6 & $229(2)$ & $8(6)$ \\
\hline DO-2 & $183(4)$ & $15(8)$ & NRF \#6P & $230(2)$ & $12(6)$ \\
\hline DO-6 & $184(4)$ & $3(8)$ & $\mathrm{NRF} \# 7$ & $231(2)$ & $23(6)$ \\
\hline DO-6A & $185(4)$ & $2(8)$ & NRF\#TP & $232(2)$ & $25(6)$ \\
\hline Dahle & $186(2)$ & $6(6)$ & NRF 89-04 & $233(2)$ & $21(6)$ \\
\hline EBR I & $187(2)$ & $11(6)$ & NRF 89-05 & $234(2)$ & $21(6)$ \\
\hline EFS Well & $188(2)$ & $18(6)$ & OW-1 & $235(4)$ & $5(8)$ \\
\hline EOCR & $189(2)$ & $3(6)$ & OW-2 & $236(4)$ & $7(8)$ \\
\hline EOCR (Disp) & $190(2)$ & $17(6)$ & PBF\#2 & $237(2)$ & $0(6)$ \\
\hline FET-Disp-1 & $191(5)$ & $40(9)$ & $\mathrm{PBF}(\mathrm{CW})$ & $238(2)$ & $0(6)$ \\
\hline GIN \#1 & $192(5)$ & $45(9)$ & PBF (WW) & $239(2)$ & $0(6)$ \\
\hline GIN \#2 & $193(5)$ & $36(9)$ & PSTF Test & $240(2)$ & $55(6)$ \\
\hline GIN \#3 & $194(5)$ & $32(9)$ & P \& W \#1 & $241(2)$ & $33(6)$ \\
\hline GIN \#4 & $195(5)$ & $36(9)$ & P \& W \#2 & $242(2)$ & $57(6)$ \\
\hline GIN \#5 & $196(5)$ & $26(9)$ & $P \& W \# 3$ & $243(2)$ & $115(6)$ \\
\hline GIN \#6 & $197(5)$ & $57(9)$ & PW-1 & $244(3)$ & $31(7)$ \\
\hline GIN \#7 & $198(5)$ & $33(9)$ & PW-2 & $245(3)$ & $17(7)$ \\
\hline GIN\#8 & $199(5)$ & $50(9)$ & PW-3 & $246(3)$ & $27(7)$ \\
\hline GIN \#9 & $200(5)$ & $49(9)$ & PW-4 & $247(3)$ & $31(7)$ \\
\hline GIN \#10 & $201(5)$ & $45(9)$ & PW-5 & $248(3)$ & $30(7)$ \\
\hline GIN\#11 & $202(5)$ & $47(9)$ & PW-6 & $249(3)$ & $37(7)$ \\
\hline GIN \#12 & $203(5)$ & $47(9)$ & PW-7 & $250(3)$ & $50(7)$ \\
\hline GIN \#13 & $204(5)$ & $6(9)$ & PW-8 & $251(3)$ & $56(7)$ \\
\hline GN \#14 & $205(5)$ & $49(9)$ & PW-9 & $252(3)$ & $49(7)$ \\
\hline GIN\#15 & $206(5)$ & $50(9)$ & PW-10 & $253(3)$ & $48(7)$ \\
\hline GIN\#16 & $207(5)$ & $38(9)$ & PW-11 & $254(3)$ & $42(7)$ \\
\hline GIN \#17 & $208(5)$ & $43(9)$ & PW-12 & $255(3)$ & $35(7)$ \\
\hline GIN\#18 & $209(5)$ & $48(9)$ & PW-13 & $256(3)$ & $39(7)$ \\
\hline GIN\#19 & $210(5)$ & $48(9)$ & PW-14 & $257(3)$ & $34(7)$ \\
\hline GIN \#20 & $211(5)$ & $8(9)$ & Quaking Aspen Butte & $258(2)$ & $11(6)$ \\
\hline Highway \#1 (piezo. A) & $212(2)$ & $6(6)$ & Well & & \\
\hline Highway \#2 & $214(2)$ & $14(6)$ & RWMC-78-1 & $259(4)$ & $15(8)$ \\
\hline Highway \#3 & $215(2)$ & $35(6)$ & RWMC-78-2 & $260(4)$ & $2(8)$ \\
\hline IET Disp. & $216(5)$ & $8(9)$ & RWMC-78-3 & $261(4)$ & $4(8)$ \\
\hline INEL \#1 & $217(2)$ & $12(6)$ & RWMC-78-4 & $262(4)$ & $2(8)$ \\
\hline Water Supply for INEL \#1 & $218(2)$ & $12(6)$ & RWMC-78-5 & $263(4)$ & $12(8)$ \\
\hline LPTF Disposal & $219(5)$ & $34(9)$ & RWMC-79-1 & $264(4)$ & $5(8)$ \\
\hline MTR Test & $220(3)$ & $49(7)$ & RWMC-79-2 & $265(4)$ & $13(8)$ \\
\hline
\end{tabular}


Table 1. Thickness of surficial sediment in wells at and near the Idaho National Engineering Laboratory-Continued

\begin{tabular}{|c|c|c|c|c|c|}
\hline Well identifier & $\begin{array}{l}\text { Map number } \\
\text { (Figure } \\
\text { number) }\end{array}$ & $\begin{array}{c}\text { Thickness } \\
\text { (Figure } \\
\text { number) }\end{array}$ & Well identifier & $\begin{array}{l}\text { Map number } \\
\text { (Figure } \\
\text { number) }\end{array}$ & $\begin{array}{c}\text { Thickness } \\
\text { (Figure } \\
\text { number) }\end{array}$ \\
\hline RWMC-79-3 & $266(4)$ & $13(8)$ & TAN\#13 & $301(5)$ & $40(9)$ \\
\hline RWMC-88-1D & $267(4)$ & $18(8)$ & TAN\#13A & $302(5)$ & $39(9)$ \\
\hline RWMC-88-02D & $268(4)$ & $6(8)$ & TAN \#14 & $303(5)$ & $39(9)$ \\
\hline RWMC-89-01D & $269(4)$ & $22(8)$ & TAN \#15 & $304(5)$ & $16(9)$ \\
\hline RWMCM1SA & $270(4)$ & $7(8)$ & TAN \#16 & $305(5)$ & $17(9)$ \\
\hline RWMC M3S & $271(4)$ & $5(8)$ & TAN\#17 & $306(5)$ & $41(9)$ \\
\hline RWMC M4D & $272(4)$ & $8(8)$ & TAN \#18 & $307(5)$ & $48(9)$ \\
\hline RWMC M6S & $273(4)$ & $7(8)$ & TAN \#19 & $308(5)$ & $47(9)$ \\
\hline RWMC M7S & $274(4)$ & $9(8)$ & TAN \#20 & $309(5)$ & $46(9)$ \\
\hline RWMC M1OS & $275(4)$ & $6(8)$ & TAN\#21 & $310(5)$ & $39(9)$ \\
\hline RWMC Prod. & $276(4)$ & $7(8)$ & TAN \#22 & $311(5)$ & $18(9)$ \\
\hline Rifie Range Well & $277(2)$ & $29(6)$ & TAN \#22A & $312(5)$ & $18(9)$ \\
\hline Leo Roger's \#1 & $278(2)$ & $3(6)$ & TAN 23 & $313(5)$ & $20(9)$ \\
\hline S5G Test (NRF \#5) & $279(2)$ & $37(6)$ & TAN \#23A & $314(5)$ & $18(9)$ \\
\hline Sdd-1 & $280(2)$ & $0(6)$ & TAN \#24 & $315(5)$ & $24(9)$ \\
\hline Sdd-2 & $281(2)$ & $0(6)$ & TAN \#24A & $316(5)$ & $22(9)$ \\
\hline Sdd-3 & $282(2)$ & $8(6)$ & TAN Drainage Disp.\#1 & $317(5)$ & $27(9)$ \\
\hline Siddoway & $283(2)$ & $72(6)$ & TAN Drainage Disp.\#2 & $318(5)$ & $24(9)$ \\
\hline Site 6 & $284(2)$ & $22(6)$ & TAN Drainage Disp.\#3 & $319(5)$ & $49(9)$ \\
\hline Site 9 & $285(2)$ & $59(6)$ & TAN Exploratory Well & $320(2)$ & $13(6)$ \\
\hline Site 14 & $286(2)$ & $313(6)$ & $\mathrm{TCH} \# 1$ & $321(5)$ & $44(9)$ \\
\hline Site 16 & $287(2)$ & $9(6)$ & TCH \#2 Piezo A & $322(5)$ & $40(9)$ \\
\hline Site 17 & $288(2)$ & $8(6)$ & TRA\#3 & $323(3)$ & $53(7)$ \\
\hline Site 19 & $289(3)$ & $49(7)$ & TRA \#4 & $324(3)$ & $40(7)$ \\
\hline TAN \#3 & $290(5)$ & $54(9)$ & TRA 05/PZ1 & $325(3)$ & $70(7)$ \\
\hline TAN \#4 & $291(5)$ & $63(9)$ & TRA 06A & $326(3)$ & $43(7)$ \\
\hline TAN \#5 & $292(5)$ & $59(9)$ & TRA 07 & $327(3)$ & $43(7)$ \\
\hline TAN \#6 & $293(5)$ & $50(9)$ & TRA 08 & $328(3)$ & $57(7)$ \\
\hline TAN\#7 & $294(5)$ & $38(9)$ & TRA Disp. & $329(3)$ & $42(7)$ \\
\hline TAN \#8 & $295(5)$ & $43(9)$ & TW-1 & $330(4)$ & $14(8)$ \\
\hline TAN \#9 & $296(5)$ & $26(9)$ & VZT-1 & $331(4)$ & $4(8)$ \\
\hline TAN\#10 & $297(5)$ & $36(9)$ & WWW\#1 & $332(4)$ & $5(8)$ \\
\hline TAN\#10A & $298(5)$ & $36(9)$ & WWW\#2 & $333(4)$ & $3(8)$ \\
\hline TAN\#11 & $299(5)$ & $36(9)$ & Water table & $334(2)$ & $3(6)$ \\
\hline TAN \#12 & $300(5)$ & $40(9)$ & Weaver and Lowe & $335(2)$ & $30(6)$ \\
\hline
\end{tabular}




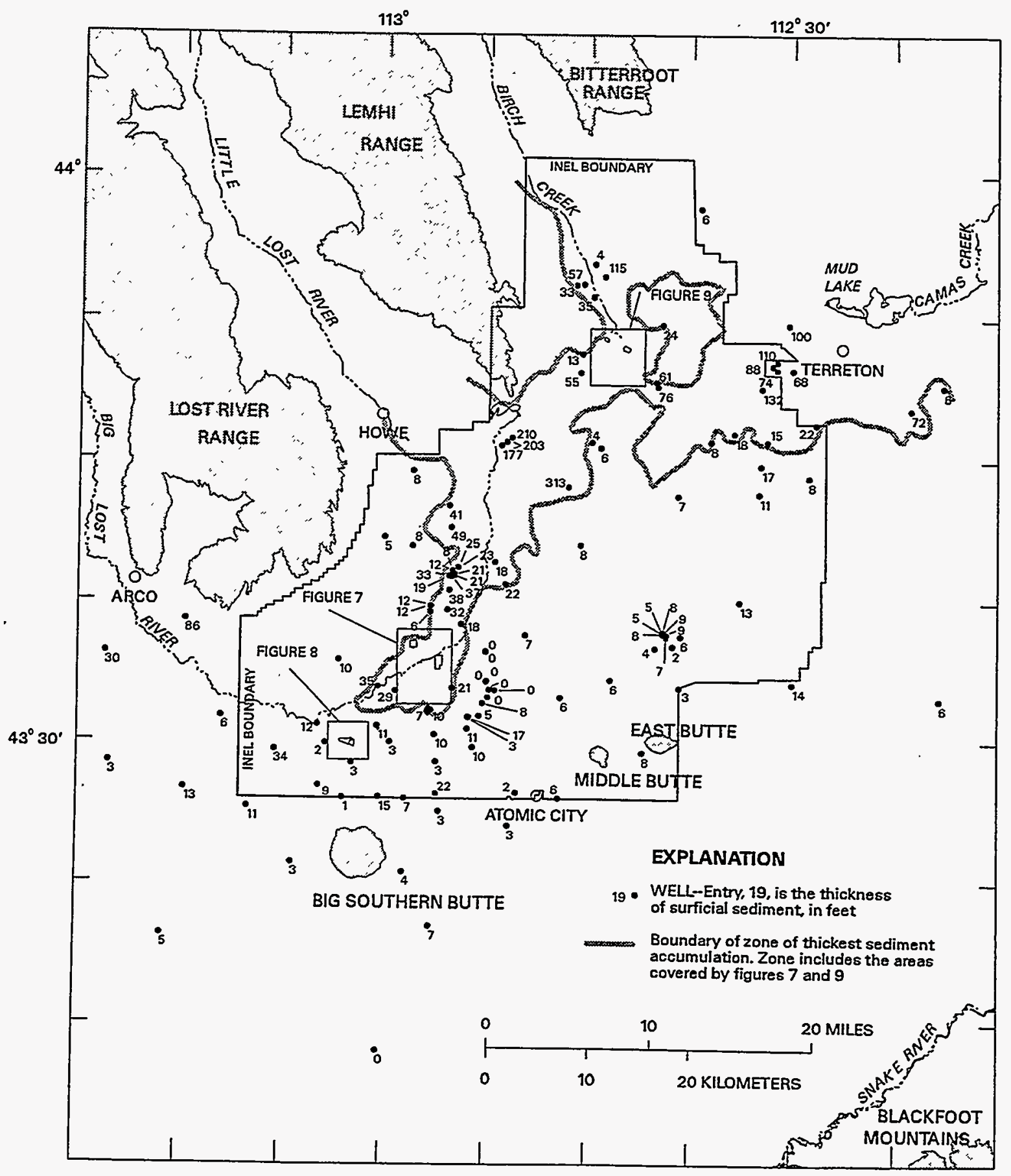

Figure 6. Thickness of surficial sediment in wells at and near the Idaho National Engineering Laboratory 


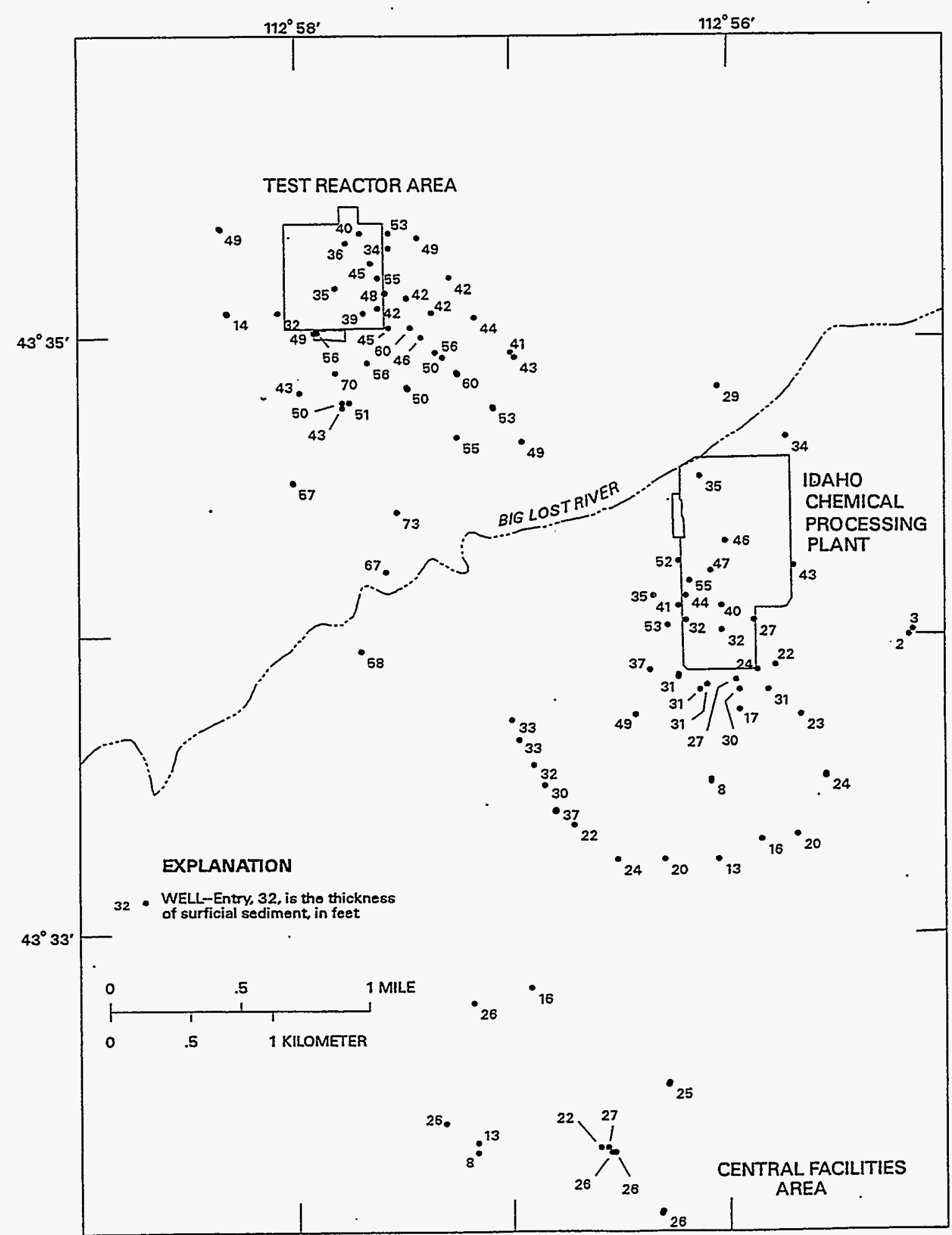

Figure 7. Thickness of surficial sediment in wells at and near the Idaho Chemical Processing Plant, Test Reactor Area, and Central Facilities Area (area keyed to figure 6). 


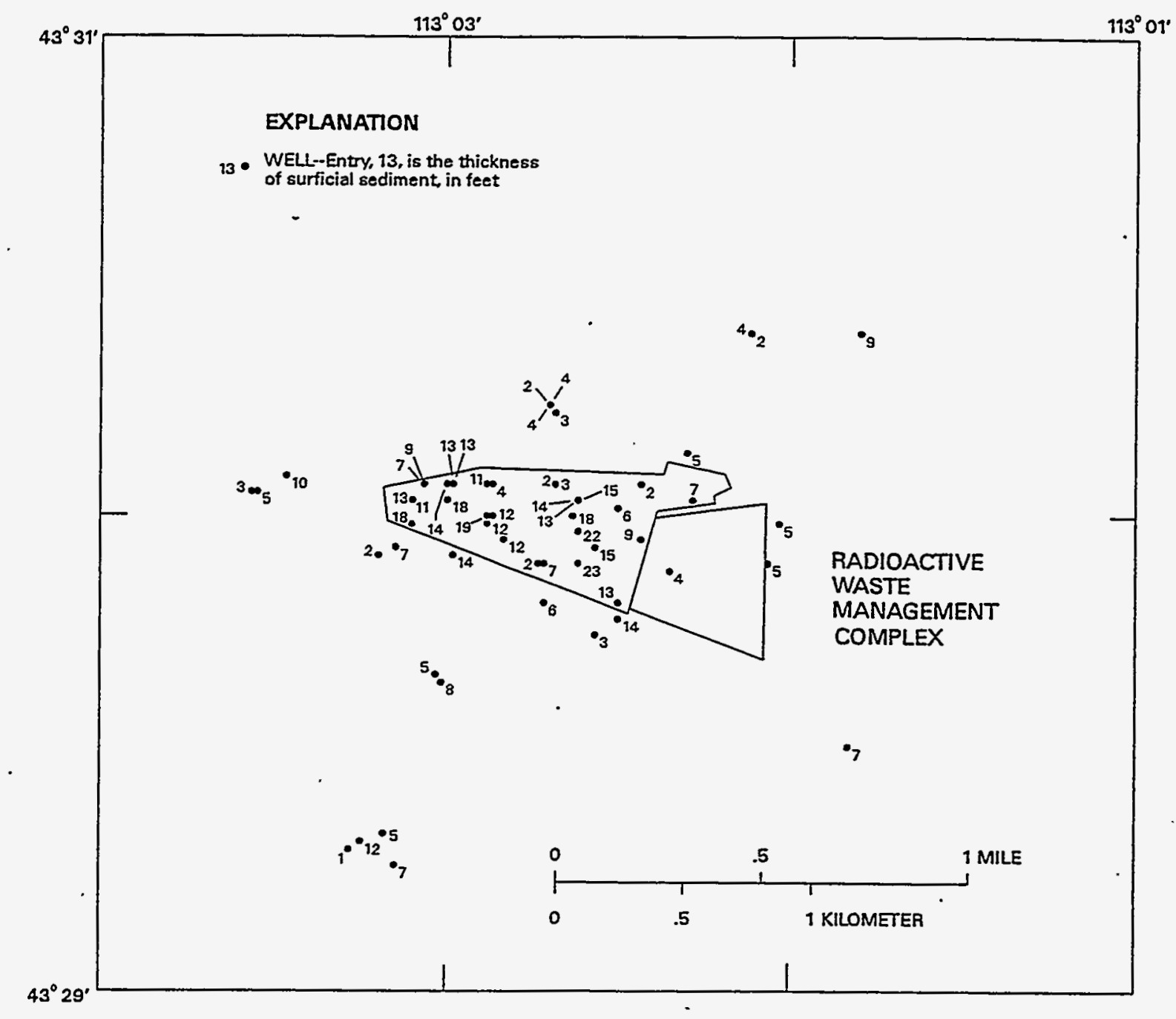

Figure 8. Thickness of surficial sediment in wells at and near the Radioactive Waste Management Complex (area keyed to figure 6). 


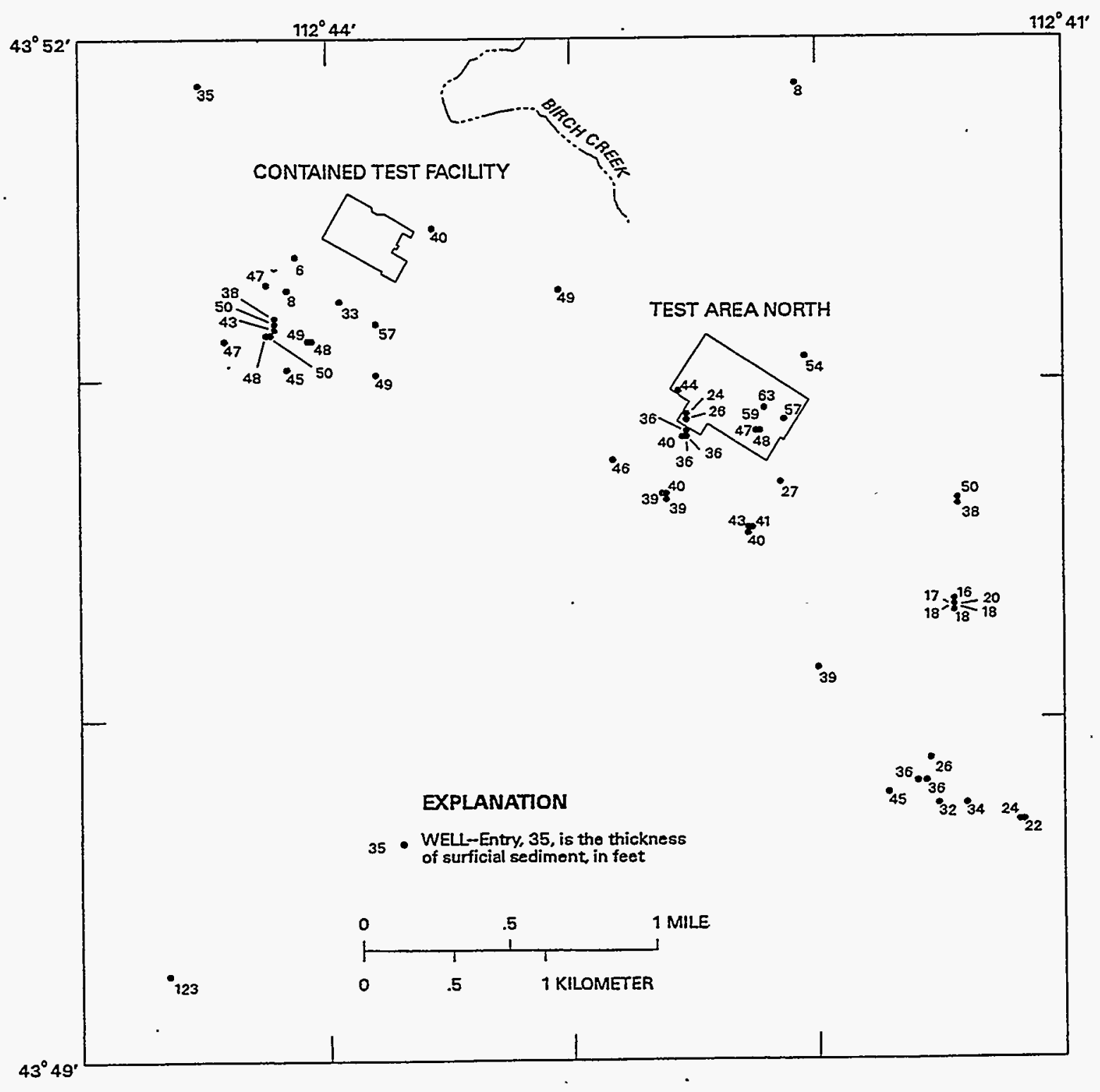

Figure 9. Thickness of surficial sediment in wells at and near the Contained Test Facility and Test Area North (area keyed to figure 6). 